\title{
Examination of "Art Literacy" Levels of Students Studying in the Education Faculties
}

\author{
Aylin Mentis Koksoy \\ Correspondence: Aylin Mentis Koksoy, Nigde Omer Halisdemir University, Turkey.
}

Received: March 5, 2018

doi:10.11114/jets.v6i5.3168
Accepted: March 28, $2018 \quad$ Online Published: April 1, 2018

URL: https://doi.org/10.11114/jets.v6i5.3168

\begin{abstract}
Art literacy refers to achieving artistic knowledge, evaluating this knowledge and integrating it with experiences. The aim of the study is to examine the "art literacy" levels of the students attending the educational faculty in terms of grade level, gender, the fact that they love art books, the fact that they love doing research in library, frequency of reading books and the department they attend. The study group consisted of 585 students attending the educational faculty of Nigde Omer Halisdemir University in 2017-2018 academic year. The art literacy scale was used to collect the data of the study. At the end of the study, it was determined that art literacy levels of students were similar in terms of class level and gender. It was realized that the art literacy level of the students enjoying reading art books was higher than the students who did not like doing so. It was also found out that the art literacy level of the students enjoying doing research in the library was higher than the students who did not like doing research. Moreover, the art literacy level of students who read books on a daily basis was higher than the students who read one book in a month and those who did not read.
\end{abstract}

Keywords: literacy, art literacy, art education

\section{Introduction}

The literacy refers to the capability of an individual to read and write by understanding short, simple expressions on the daily life (Keefe, E.B. \& Copeland R.S. 2011). In addition, literacy is the ability to read and write at a level assuring the communication between the individuals, by using written or visual symbols. Nowadays, the literacy is also used for referring to a well-educated person having an extensive knowledge on a certain field (Kışoğlu, 2009). Today, it is possible to mention the literacy in many different fields such as media literacy, information literacy, computer literacy, environmental literacy, visual literacy, music literacy as well as art literacy (Tallim, 2010; Gündüz-Kalan, 2008; Güneş, Çolaklar, Biçen-Aras \& Turan, 2013; Kurbanoğlu \& Akkoyunlu, 2002; Roth, 2002; Akt. Timur B., Yılmaz \& Timur S., 2014, p. 23; Heinich, Molenda and Russel, 1989; Alpan-Bangir, 2008; Csíkos \& Dohány, 2016).

On the other hand, art literacy is defined as the ability to contribute to and understand concrete issues involving visual arts (painting, drawing, pottery, etc.). Hence, it includes the knowledge and understanding, necessary to participate really in the arts. (National Core Arts Standards, p. 17). Art literacy, "is a type of literacy that enables to establish an eclectic relationship between the international arts that may be indirectly accessed and the local arts that is directly perceived in the globalized world, to access the knowledge that can be needed in the professional and individual lives of the individuals who perform the arts as a profession. By this way, the individual may transfer the accessed information to the applications" (Yücetoker, 2014). Art teachers describe the art literacy in two interrelated perspectives. While the first is literacy in a particular context, the other perspective considers the literacy as the competency in a deeper disciplinary context to use the learned skills to become artists. (Barton, GM, 2013). When each of these stages is examined, the individual shall know where and how s/he can access the missing information about art, comprehend the sources to access artistic information, evaluate the obtained information in a conceptual framework, understand where and how s/he can use the evaluated information and finally, combine the obtained information with the applications s/he is going to perform (Okan-Akın, Yücetoker, 2016). Hence, the art education constitutes one of the most reliable environments, in which creativity is prioritized, divergent thinking is developed and each student is guided in parallel to his/her personal development and tendencies. Since the purpose of the art education is directing the child/youth for seeing, searching, asking, experimenting and concluding, the art education should continue without interruption at every stage of education (Buyurgan S., Buyurgan U., 2012). One of the utmost prominent purposes of art education is teaching to see, hear, touch, taste. Thus, the proper perception of the environment is the prerequisite for shaping it. For 
creativity, looking is not enough, it is necessary to "see", while the hearing is not enough, it is necessary to "understand". Also, it is not enough just to touch, but it is necessary to "understand what is touched" (San, 1985).

Thanks to art education, the individual may interact with the cultural environment and communicate; hence, s/he will be more powerful and understandable. The art education aims to train creative and constructive individuals who have a developed visual perception, who are capable of expressing themselves through artistic way and recognize, learn, protect the culture they live in, assume the responsibility for communicating the culture to future generations and respect the world's cultural heritage. Hence, it is important to attach importance to the art education with appropriate programs at every level of education, without interruption, for achieving these objectives. However, there is no sufficient study conducted in this field. Thus, the purpose of this study is to determine the art literacy levels of students studying at the faculty of education, to inform about literacy applications and to enable them to use the conceptual knowledge in the art applications.

In order to achieve and evaluate the results in light of this objective, the following sub-objectives were required to be included in the study.

Among art literacy of the students studying at the education faculty;

- Is there a difference in terms of class level?

- Is there a difference in terms of gender?

- Is there any difference in terms of enjoyment of reading art books?

- Is there any difference in terms of enjoyment from doing research in the library?

- Is there any difference in terms of reading frequency?

- Is there a difference in terms of the levels of the department?

\section{Method}

\subsection{Research Model}

This study, aiming to examine whether gender, class level, enjoyment of reading books, enjoyment of using the library, reading frequency and department variables, is designed as a causal-comparative study. Fraenkel, Wallen, and Hyun (2011) reported in their causal-comparative study that researchers are striving to examine the causes or consequences of differences between groups of individuals.

\subsection{Study-Group}

The study group of the research consisted of 585 undergraduates attending the Faculty of Education at Nigde Omer Halisdemir University, who were volunteers to participate. (396 of whom are female, 189 of whom are male). 149 undergraduates attending the department of primary education, 124 undergraduates attending the department of Social Science teaching, 42 undergraduates studying Turkish teaching, 59 undergraduates from the department Psychological Counselling and Guidance, 92 undergraduates from Maths teaching, 89 undergraduates from Science teaching and 30 undergraduates attending ICT, who were at the $3^{\text {rd }}$ or $4^{\text {th }}$ grade, took part in the research.

\subsection{Data Collection Tools}

The "Art Literacy Scale" created by Yücetoker (2014) was used as data collection tool in the study. The art literacy scale is classified using 5-response Likert type scale; "I don't have difficulty at all", "I don't have difficulty", "I am indecisive", "I have difficulty" and "I have little difficulty". The scale consists of 4 sub-factors as "Using Art Literacy Knowledge", "Defining Information Need for Art Literacy", "Transferring Art Literacy Knowledge into Performance", "Reaching Art Literacy Information".

\subsection{Data Analysis}

The data-set was examined before starting the data analysis in the study. It is ascertained that there is no value, which was wrongly entered in the dataset and there is no missing data. Z-scores were calculated to comprehend if there were outliers in the data set. In this direction, it was found that four observations exceed 3. 29 in $\mathrm{Z}$ scores. Thus, these observations have been removed from the dataset. For the assumption of normality, skewness and kurtosis values and histogram graphs are examined. It was found that the skewness and kurtosis values were approaching zero. When the histogram graphs were examined, it was comprehended that the data set fulfills the requirements for the assumption of normality. For the homogeneity of the variances, a Levene's test was performed and it was observed that the assumption for homogeneity of variances is fulfilled. In the light of these results, independent groups t-test and one-way variance analysis techniques were used for data analysis. The margin of error in the study was accepted as .05 . 


\section{Findings}

Independent groups t-test technique was used to examine whether art literacy varied in terms of class level, gender, enjoyment of reading and enjoyment of using the library, and the findings are revealed in the following tables.

\subsection{Findings on Art Literacy in Terms of Class Level Variance}

Table-1a. Examining the art literacy knowledge in terms of class level

\begin{tabular}{lllll}
\hline Class Level & $\mathbf{n}$ & $\boldsymbol{M}$ & $\boldsymbol{S D}$ & $\boldsymbol{t}$ \\
\hline 3rd Grade & 306 & 31,74 & 6,56 & \multirow{2}{*}{.78 } \\
\hline 4th Grade & 279 & 32,15 & 6,02 & \\
\hline
\end{tabular}

There is no significant difference in the level of using art literacy knowledge in terms of class level variables $(t(583)=$ $-.78, p>05)$. In other words, the levels of using the art literacy knowledge of the third and fourth-grade students studying in the education faculty are similar.

Table-1b. Examination of defining information need for art literacy in terms of class level

\begin{tabular}{lllll}
\hline Class Level & $\mathrm{n}$ & $\mathrm{M}$ & $\mathrm{SD}$ & $\mathrm{t}$ \\
\hline 3rd Grade & 306 & 16,35 & 3,47 & \\
\cline { 1 - 4 } 4th Grade & 279 & 16,72 & 3,48 & \\
\cline { 1 - 4 } & &
\end{tabular}

There is no significant difference in the level of defining information need for art literacy in terms of class level variance $(t(583)=-1.27, p>.05)$. In other words, the levels of defining the information need for art literacy of $3^{\text {rd }}$ and $4^{\text {th }}$-grade students studying in the education faculty are similar.

Table-1c. Examination of transferring art literacy knowledge into performance in terms of class level

\begin{tabular}{lllll}
\hline Class Level & $\mathbf{n}$ & $\boldsymbol{M}$ & $\boldsymbol{S D}$ & $\boldsymbol{t}$ \\
\hline 3rd Grade & 306 & 19,78 & 4,98 & \multirow{2}{*}{$-1,06$} \\
\cline { 1 - 4 } 4th Grade & 279 & 20,19 & 4.25 &
\end{tabular}

There is no significant difference in the level of transferring art literacy knowledge into performance in terms of class level variance $(t(583)=-1.06, p>.05)$. In other words, the levels of transferring art literacy knowledge into the performance of 3rd and 4th-grade students studying in the education faculty are similar.

Table-1d. Examination of reaching art literacy information in terms of class level

\begin{tabular}{lllll}
\hline Class Level & $\mathbf{n}$ & $\boldsymbol{M}$ & $\boldsymbol{S D}$ & $\boldsymbol{t}$ \\
\hline 3rd Grade & 306 & 17,92 & 3,80 & \multirow{2}{*}{02} \\
\hline 4th Grade & 279 & 17,91 & 3,51 & \\
\hline
\end{tabular}

There is no significant difference in the level of reaching art literacy information in terms of class level variance $(t(583)=.02, p>05)$. In other words, the level of reaching the art literacy information of 3rd and 4th-grade students, studying in education faculty, is similar.

\subsection{Findings on Art Literacy in Terms of Gender Variance}

Table-2a. Examination of using the art literacy knowledge in terms of gender

\begin{tabular}{lllll}
\hline Gender & $\mathbf{n}$ & $\boldsymbol{M}$ & $\boldsymbol{S D}$ & $\boldsymbol{t}$ \\
\cline { 1 - 4 } Female & 396 & 31,91 & 6,21 & \\
\cline { 1 - 4 } Male & 189 & 32,00 & 6,51 &
\end{tabular}

There is no significant difference in the level of using art literacy information in terms of gender variance $(t(583)=-.17$, $p>$.05). In other words, the level of using the art literacy of male and female students are similar.

Table-2b. Examination of defining the information need for art literacy in terms of gender

\begin{tabular}{lllll}
\hline Gender & $\mathbf{n}$ & $\boldsymbol{M}$ & $\boldsymbol{S D}$ & $\boldsymbol{t}$ \\
\cline { 1 - 4 } Female & 396 & 16,43 & 3,43 & \\
\cline { 1 - 4 } Male & 189 & 16,73 & 3,57 &
\end{tabular}

There is no significant difference in the $\overline{\text { level of defining information need for }}$ art literacy in terms of gender variable 
$(t(583)=-.97, p>.05)$. In other words, the levels of defining information need for art literacy of male and female students are similar.

Table-2c. Examination of transferring art literacy knowledge into performance in terms of gender

\begin{tabular}{lllll}
\hline Gender & $\mathbf{n}$ & $\boldsymbol{M}$ & $\boldsymbol{S D}$ & $\boldsymbol{t}$ \\
\hline Female & 396 & 19,98 & 4,71 & \\
\cline { 1 - 3 } Male & 189 & 19,96 & 4,53 &
\end{tabular}

There is no significant difference in the level of transferring art literacy knowledge into performance in terms of gender variable $(t(583)=.05, p>.05)$. In other words, the levels of transferring art literacy knowledge into the performance of female and male students are similar.

Table-2d. Examination of reaching the art literacy information in terms of gender

\begin{tabular}{lllll}
\hline Gender & $\mathbf{n}$ & $\boldsymbol{M}$ & $\boldsymbol{S D}$ & $\boldsymbol{t}$ \\
\hline Female & 396 & 17,76 & 3,54 & $-1,52$ \\
\hline Male & 189 & 18,25 & 3,87 & \\
\hline
\end{tabular}

There is no significant difference in the level of reaching the art literacy information in terms of gender variable $(t(583)=-1.52, p>.05)$. The levels of reaching art literacy information of male and female students are similar.

3.3 Findings on the Art Literacy in Terms of the Enjoyment of Reading Art Books

Table-3a. Examination of using the art literacy knowledge in terms of enjoyment of reading art books

\begin{tabular}{lllll}
\hline Enjoyment of reading art books & $\mathbf{n}$ & $\boldsymbol{M}$ & $\boldsymbol{S D}$ & $\boldsymbol{t}$ \\
\hline Yes & 236 & 34,05 & 5,88 & \multirow{2}{*}{$6,91^{*}$} \\
\cline { 1 - 4 } No & 349 & 30,52 & 6,20 & \\
\hline
\end{tabular}

$* \mathrm{p}<.05$

There is a significant difference in the level of using art literacy information of art students in terms of enjoying reading art books $(t(583)=6.91, p<.05)$. In other words, the level of using the art literacy by individuals who enjoy reading art books is higher than those who do not enjoy reading art books.

Table-3b. Examination of defining the information need for art literacy in terms of the enjoyment of reading art books

\begin{tabular}{lllll}
\hline Enjoyment of reading art books & $\mathbf{n}$ & $\boldsymbol{M}$ & $\boldsymbol{S} \boldsymbol{D}$ & \multicolumn{1}{c}{$\boldsymbol{t}$} \\
\cline { 1 - 4 } Yes & 236 & 17,60 & 3,20 & \multirow{2}{*}{$6,33^{*}$} \\
\cline { 1 - 4 } No & 349 & 15,80 & 3,47 & \\
\hline
\end{tabular}

$* \mathrm{p}<.05$

There is a significant difference in the level of describing information need for art literacy in terms of enjoyment of reading art books variable $(t(583)=6.33, p<.05)$. In other words, the level of defining the information need for art literacy is higher in the students enjoying reading art books in comparison with the ones who do not enjoy reading art books.

Table 3c. Examination of transferring art literacy knowledge into performance in terms of enjoyment of reading art books

\begin{tabular}{|c|c|c|c|c|}
\hline Enjoyment of reading art books & $\mathbf{n}$ & $M$ & $S D$ & $t$ \\
\hline Yes & 236 & 21,07 & 4,77 & \multirow{2}{*}{$4,78 *$} \\
\hline No & 349 & 19,23 & 4,42 & \\
\hline
\end{tabular}

$* \mathrm{p}<.05$

There is a significant difference in the level of transferring art literacy knowledge into performance in terms of enjoyment of reading art books variance $(t(583)=4.78, p<.05)$. In other words, the level of transferring art literacy knowledge into the performance of students who enjoy reading art books is higher than those who dislike reading art books. 
Table 3d. Examination of reaching the art literacy information in terms of enjoyment of reading art books

\begin{tabular}{lllll}
\hline Enjoyment of reading art books & $\mathbf{n}$ & $\boldsymbol{M}$ & $\boldsymbol{S D}$ & $\boldsymbol{t}$ \\
\hline Yes & 236 & 18,58 & 3,44 & \multirow{2}{*}{$3,63^{*}$} \\
\cline { 1 - 4 } No & 349 & 17,47 & 3,74 & \\
\hline
\end{tabular}

$* \mathrm{p}<.05$

There is a significant difference in the level of reaching art literacy information in terms of the enjoyment of reading art books variable $(t(583)=3.63, p<.05)$. In other words, the level of reaching the art literacy information is higher in students enjoying reading art books in comparison to those who dislike reading art books.

3.4 Findings of Art Literacy in Terms of Enjoyment of Doing Research in the Library

Table-4a. Examining the use of the art literacy knowledge in terms of the enjoyment of doing research in the library

\begin{tabular}{lllll}
\hline Enjoyment of doing research in the library & $\mathbf{n}$ & $\boldsymbol{M}$ & $\boldsymbol{S} \boldsymbol{D}$ & $\boldsymbol{t}$ \\
\hline Yes & 362 & 32,63 & 6,15 & \multirow{2}{*}{$3,40^{*}$} \\
\hline No & 223 & 30,82 & 6,42 & \\
\hline
\end{tabular}

$* \mathrm{p}<.05$

There is a significant difference in the level of using the art literacy information of students in terms of enjoyment of doing research in the library $(t(583)=3.40, p<.05)$. In other words, the level of using the art literacy knowledge by individuals who enjoy doing research in the library is higher than those who do not.

Table 4b. Examining the definition of information need for art literacy in terms of enjoyment of doing research in the study

\begin{tabular}{lllll}
\hline Enjoyment of doing research in the library & $\mathbf{n}$ & $\boldsymbol{M}$ & $\boldsymbol{S D}$ & $\boldsymbol{t}$ \\
\hline Yes & 362 & 16,94 & 3,34 & \multirow{2}{*}{$3,74^{*}$} \\
\hline No & 223 & 15,85 & 3,58 & \\
\hline
\end{tabular}

$* \mathrm{p}<.05$

There is a significant difference in the level of defining the information need for art literacy in terms of enjoyment of doing research in the library $(t(583)=3.74, p<.05)$. In other words, the level of defining information need for art literacy is higher in the students who enjoy doing research in the library than those who do not.

Table 4c. Examination of transferring art literacy knowledge into performance in terms of enjoyment of doing research in the library

\begin{tabular}{lllll}
\hline Enjoyment of doing researches in the library & $\mathbf{n}$ & $\boldsymbol{M}$ & $\boldsymbol{S} \boldsymbol{D}$ & $\boldsymbol{t}$ \\
\hline Yes & 362 & 20,50 & 4,78 & \multirow{2}{*}{$3,51^{*}$} \\
\cline { 1 - 4 } No & 223 & 19,12 & 4,31 & \\
\hline
\end{tabular}

$* \mathrm{p}<.05$

There is a significant difference in the level of transferring knowledge of art literacy into performance in terms of enjoyment of doing research in the library $(t(583)=3.51, p<.05)$. In other words, the level of transferring art literacy knowledge into performance is higher in the students who enjoy doing research in the library than those who do not.

Table 4d. Examination of reaching art literacy information in terms of enjoyment of doing research in the library

\begin{tabular}{lllll}
\hline Enjoyment of doing research in the library & $\mathbf{n}$ & $\boldsymbol{M}$ & $\boldsymbol{S D}$ & $\boldsymbol{t}$ \\
\hline Yes & 362 & 18,27 & 3,48 & \multirow{2}{*}{$3,02^{*}$} \\
\hline No & 223 & 17,34 & 3,86 & \\
\hline
\end{tabular}

$* \mathrm{p}<.05$

There is a meaningful difference in the level of reaching the art literacy information in terms of enjoyment of doing research in the library $(t(583)=3.02, p<.05)$. In other words, the level of reaching the art literacy information is higher in the students who enjoy doing research in the library than those who do not.

\subsection{Findings Related to Art Literacy in Terms of Reading Frequency}

One-way ANOVA technique was used to analyze whether there was a significant difference in using the art literacy 
knowledge, defining the information need for art literacy, transferring the art literacy knowledge into performance and reaching the art literacy information in terms of frequency of reading.

Table 5a. Examination of art literacy in terms of frequency of reading books

\begin{tabular}{|c|c|c|c|c|c|c|c|c|c|c|c|}
\hline Dimension & & $\begin{array}{l}\text { Reading } \\
\text { Frequency }\end{array}$ & $\mathbf{n}$ & $M$ & Variance Source & $\begin{array}{l}\text { Sum } \\
\text { Squares }\end{array}$ & Of & sd & $\begin{array}{l}\text { Average } \\
\text { of } \\
\text { Squares }\end{array}$ & $\mathbf{F}$ & Variance \\
\hline \multirow{5}{*}{$\begin{array}{l}\text { Using art } \\
\text { knowledge }\end{array}$} & \multirow{5}{*}{ literacy } & Daily & 67 & 35,20 & Between & 116500 & & 4 & 2912 & \multirow{5}{*}{$7,65^{*}$} & \multirow{5}{*}{$\begin{array}{l}1-2 \\
1-4 \\
1-5\end{array}$} \\
\hline & & Once a Week & 92 & 31,92 & Groups & 1165,09 & & 4 & 291,21 & & \\
\hline & & Twice a week & 57 & 33,07 & Within the Groups & 22079,04 & & 580 & 38,67 & & \\
\hline & & Once a month & 273 & 31,58 & \multirow{2}{*}{ Total } & \multirow{2}{*}{23244,14} & \multirow{2}{*}{\multicolumn{2}{|c|}{584}} & & & \\
\hline & & I do not read & 96 & 30,04 & & & & & & & \\
\hline
\end{tabular}

In terms of frequency of reading books, a significant difference was found in the level of using art literacy information $(F(4,580)=7.65, p<.05)$. Tukey test was conducted to determine the source of the difference. In this respect, the level of using art literacy knowledge is higher in students who read books daily than those who read a book once a month or who do not read at all.

Table 5b. Examination of defining information need for art literacy in terms of frequency of reading books

\begin{tabular}{|c|c|c|c|c|c|c|c|c|c|}
\hline Dimension & Reading Frequency & $\mathbf{n}$ & $M$ & $\begin{array}{l}\text { Variance } \\
\text { Source }\end{array}$ & $\begin{array}{l}\text { Sum of } \\
\text { Squares }\end{array}$ & sd & $\begin{array}{l}\text { Average } \\
\text { of } \\
\text { Squares }\end{array}$ & $\mathbf{F}$ & Variance \\
\hline \multirow{6}{*}{$\begin{array}{l}\text { Defining } \\
\text { information } \\
\text { for art literacy }\end{array}$} & 1. Daily & 67 & 18,22 & Between the & & 4 & & \multirow{6}{*}{$6,85^{*}$} & \multirow{6}{*}{$\begin{array}{l}1-4 \\
1-5\end{array}$} \\
\hline & Once a Week & 92 & 16,69 & Groups & 317,90 & 4 & 79,48 & & \\
\hline & Twice & 57 & 16,81 & Within the & & 580 & 11,60 & & \\
\hline & Week & & & Groups & 6728,56 & & & & \\
\hline & $\begin{array}{ll}\text { 4. } & \begin{array}{l}\text { Once } \\
\text { month }\end{array}\end{array}$ & 273 & 16,38 & \multirow[t]{2}{*}{ Total } & \multirow[t]{2}{*}{7046,46} & \multirow[t]{2}{*}{584} & & & \\
\hline & 5. I do not read & 96 & 15,45 & & & & & & \\
\hline
\end{tabular}

In terms of frequency of reading books, there is a significant difference in the level of defining information need for art literacy $(F(4,580)=6.85, p<.05)$. Tukey test was conducted to determine the source of the difference. In this respect, the level of defining information need for art literacy is higher in students who read books daily than those who read a book once a month or who do not read at all.

Table 5c. Examination of transferring art literacy knowledge into performance in terms of frequency of reading books

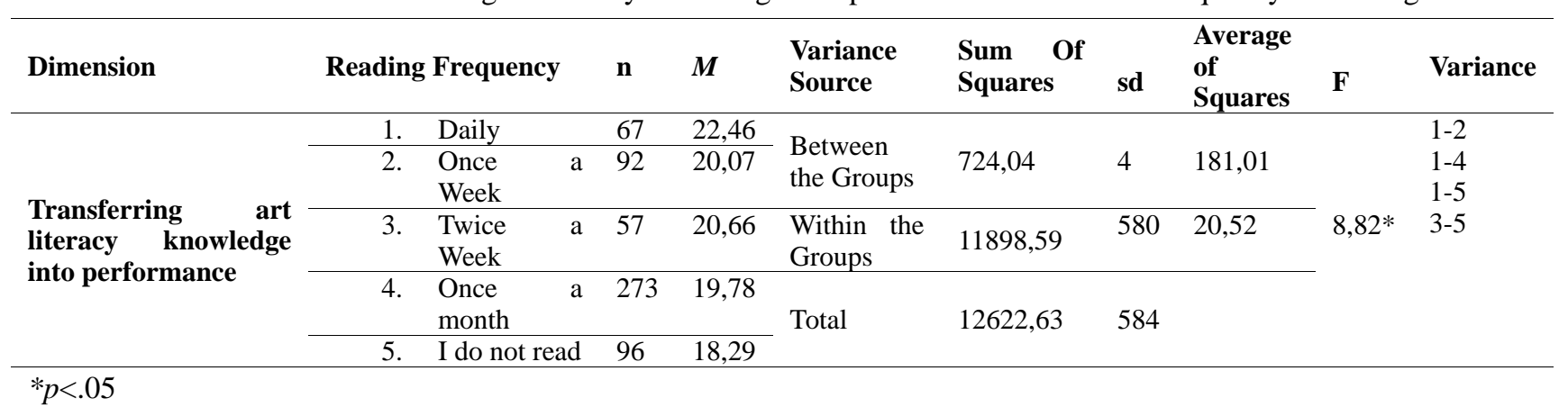

In terms of the frequency of reading books, it was ascertained that there was a significant difference in the level of transferring art literacy knowledge into performance $(F(4,580)=8.82, p<.05)$. Tukey test was conducted to determine the source of the difference. At the end of the Tukey test, the level of transferring art literacy knowledge into performance is higher in students who read books daily than those who read a book once a month or who do not read at all. The level of transferring art literacy knowledge into performance in students who read books twice a week is higher than those who never read. 
Table 5d. Examination of reaching art literacy information in terms of frequency of reading books

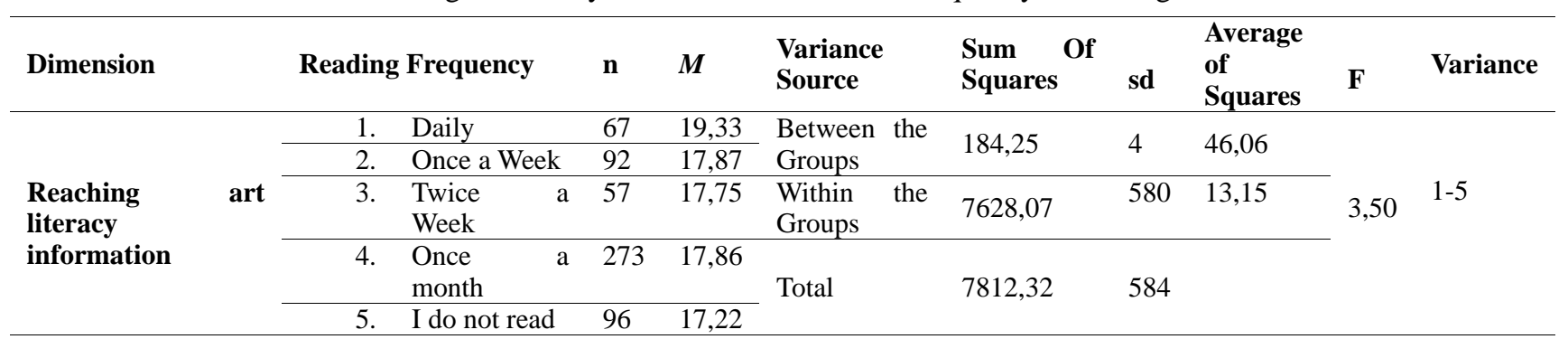

$*_{p}<.05$

There is a significant difference in the level of reaching the art literacy information in terms of frequency of reading books $(F(4,580)=3.50, p<.05)$. Tukey test was conducted to determine the source of the difference. At the end of Tukey test, the level of reaching art literacy information is higher in the students who read daily than those who do not read at all.

\subsection{Examination of Art Literacy in Terms of Department Variable}

Table 6a. Examination of the level of using art literacy knowledge in terms of department variance

\begin{tabular}{|c|c|c|c|c|c|c|c|c|c|c|}
\hline Dimension & & Department & $\mathbf{n}$ & $M$ & $\begin{array}{l}\text { Variance } \\
\text { Source }\end{array}$ & $\begin{array}{l}\text { Sum Of } \\
\text { Squares }\end{array}$ & sd & $\begin{array}{l}\text { Average } \\
\text { of } \\
\text { Squares }\end{array}$ & $\mathbf{F}$ & Variance \\
\hline \multirow{7}{*}{$\begin{array}{l}\text { Using } \\
\text { literacy } \\
\text { knowledge }\end{array}$} & \multirow{7}{*}{ art } & 1. Classroom teaching & 149 & 31,88 & & & & & \multirow{7}{*}{$4.02 *$} & \multirow{7}{*}{$\begin{array}{l}3-4 \\
3-5\end{array}$} \\
\hline & & $\begin{array}{l}2 . \quad \text { Social } \quad \text { Sciences } \\
\text { Teaching }\end{array}$ & 124 & 32,40 & $\begin{array}{l}\text { Between the } \\
\text { Groups }\end{array}$ & 930,85 & 6 & 155,14 & & \\
\hline & & 3. Turkish Teaching & 42 & 35,48 & $\begin{array}{l}\text { Within the } \\
\text { Groups }\end{array}$ & 22313,28 & 578 & 38,60 & & \\
\hline & & $\begin{array}{l}\text { 4. Psychological } \\
\text { Counseling and Guidance }\end{array}$ & 59 & 29,96 & \multirow{4}{*}{ Total } & \multirow{4}{*}{23244,14} & \multirow{4}{*}{584} & & & \\
\hline & & 5. Mathematics Teaching & 92 & 30,72 & & & & & & \\
\hline & & 6. Science Teaching & 89 & 32,25 & & & & & & \\
\hline & & $\begin{array}{l}\text { 7. Computer Education } \\
\text { and } \\
\text { Technology }\end{array}$ & 30 & 32,07 & & & & & & \\
\hline
\end{tabular}

In terms of department variance, there was a significant difference in the level of using art literacy information $(F(6$, $578)=4.02, p<.05)$. Tukey test was conducted to determine the source of the difference. In this respect, the level of using art literacy knowledge of students studying in Turkish teaching department is higher than students of psychological counseling and mathematics teaching.

Table 6b. Examination of defining information need for art literacy in terms of department variable

\begin{tabular}{|c|c|c|c|c|c|c|c|c|c|}
\hline Dimension & Department & $\mathbf{n}$ & $M$ & $\begin{array}{l}\text { Variance } \\
\text { Source }\end{array}$ & $\begin{array}{ll}\text { Sum of } \\
\text { Squares }\end{array}$ & sd & $\begin{array}{l}\text { Average of } \\
\text { Squares }\end{array}$ & $\mathbf{F}$ & Variance \\
\hline \multirow{8}{*}{$\begin{array}{l}\text { Defining } \\
\text { information need } \\
\text { for art literacy }\end{array}$} & $\begin{array}{ll}1 . & \text { Classroom } \\
\text { teaching } & \end{array}$ & 149 & 16,57 & \multirow{2}{*}{$\begin{array}{l}\text { Between } \\
\text { Groups }\end{array}$} & \multirow[b]{2}{*}{202,87} & \multirow[b]{2}{*}{6} & \multirow[b]{2}{*}{33,81} & \multirow{8}{*}{$2,86^{*}$} & \\
\hline & $\begin{array}{l}\text { 2. Social Sciences } \\
\text { Teaching }\end{array}$ & 124 & 16,52 & & & & & & $3-4$ \\
\hline & 3. Turkish Teaching & 42 & 18,12 & $\begin{array}{l}\text { Within the } \\
\text { Groups }\end{array}$ & 6843,59 & 578 & 11,84 & & $3-5$ \\
\hline & $\begin{array}{l}4 . \quad \text { Psychological } \\
\text { Counseling and } \\
\text { Guidance }\end{array}$ & 59 & 15,83 & \multirow{5}{*}{ Total } & \multirow{5}{*}{7046,46} & \multirow{5}{*}{584} & & & \\
\hline & 5. Mathematics & 92 & 15,85 & & & & & & \\
\hline & Teaching & & & & & & & & \\
\hline & 6. Science Teaching & 89 & 16,57 & & & & & & \\
\hline & $\begin{array}{l}7 . \quad \text { Computer } \\
\text { Education and } \\
\text { Instructional } \\
\text { Technology }\end{array}$ & 30 & 17,43 & & & & & & \\
\hline
\end{tabular}

In terms of department variable, it was revealed that there was a significant difference in the level of defining information need for art literacy $(F(6,578)=2.86, p<.05)$. Tukey test was conducted to determine the source of the difference. In this respect, the level of defining the information need for art literacy of students studying at Turkish 
teaching department is higher than the students studying at psychological counseling and mathematics teaching.

Table 6c. Examination of transferring art literacy knowledge into performance in terms of department variable

\begin{tabular}{|c|c|c|c|c|c|c|c|c|}
\hline Dimension & Department & $\mathbf{n}$ & $M$ & $\begin{array}{l}\text { Variance } \\
\text { Source }\end{array}$ & $\begin{array}{l}\text { Sum of } \\
\text { Squares }\end{array}$ & sd & $\begin{array}{l}\text { Average } \\
\text { of } \\
\text { Squares }\end{array}$ & $\mathbf{F}$ \\
\hline \multirow{7}{*}{$\begin{array}{l}\text { Transferring } \\
\text { knowledge } \\
\text { performance }\end{array}$} & 1. Classroom teaching & 149 & 20,03 & \multirow{2}{*}{$\begin{array}{l}\text { Between the } \\
\text { Groups }\end{array}$} & \multirow{2}{*}{159,93} & \multirow{2}{*}{6} & \multirow{2}{*}{26,66} & \multirow{7}{*}{1,24} \\
\hline & 2. Social Sciences Teaching & 124 & 20,17 & & & & & \\
\hline & 3. Turkish Teaching & 42 & 21,26 & $\begin{array}{l}\text { Within the } \\
\text { Groups }\end{array}$ & 12462,70 & 578 & 21,56 & \\
\hline & 4. $\quad$ Psychological & 59 & 19,44 & \multirow{4}{*}{ Total } & \multirow{4}{*}{12622,63} & \multirow{4}{*}{584} & & \\
\hline & $\begin{array}{l}\text { Counseling and Guidance } \\
\text { 5. Mathematics Teaching }\end{array}$ & 92 & 19.37 & & & & & \\
\hline & 6. Science Teaching & 89 & 20,30 & & & & & \\
\hline & $\begin{array}{l}\text { 7. Computer Education and } \\
\text { Instructional Technology }\end{array}$ & 30 & 19,05 & & & & & \\
\hline
\end{tabular}

Table 6d. Examining of reaching art literacy information in terms of department variance

\begin{tabular}{|c|c|c|c|c|c|c|c|c|}
\hline Dimension & Department & $\mathbf{n}$ & $M$ & $\begin{array}{l}\text { Variance } \\
\text { Source }\end{array}$ & $\begin{array}{l}\text { Sum } \\
\text { Squares }\end{array}$ & Of & $\begin{array}{l}\text { Average of } \\
\text { Squares }\end{array}$ & $\mathbf{F}$ \\
\hline \multirow{9}{*}{$\begin{array}{l}\text { Using art literacy } \\
\text { knowledge }\end{array}$} & $\begin{array}{ll}1 . & \text { Classroom } \\
\text { teaching } & \end{array}$ & 149 & 17,69 & \multirow{2}{*}{$\begin{array}{l}\text { Between the } \\
\text { Groups }\end{array}$} & \multirow{2}{*}{167,51} & \multirow{2}{*}{6} & \multirow{2}{*}{27,92} & \multirow{9}{*}{2,01} \\
\hline & $\begin{array}{l}\text { 2. Social Sciences } \\
\text { Teaching }\end{array}$ & 124 & 17,77 & & & & & \\
\hline & 3. Turkish Teaching & 42 & 17,95 & $\begin{array}{l}\text { Within the } \\
\text { Groups }\end{array}$ & 7644,82 & 578 & 13,23 & \\
\hline & $\begin{array}{l}\text { 4. Psychological } \\
\text { Counseling and } \\
\text { Guidance }\end{array}$ & 59 & 17,01 & \multirow{6}{*}{ Total } & \multirow{6}{*}{7812,32} & \multirow{6}{*}{584} & & \\
\hline & 5. Mathematics & 92 & 18,06 & & & & & \\
\hline & Teaching & & & & & & & \\
\hline & 6. Science Teaching & 89 & 18,33 & & & & & \\
\hline & Computer & 30 & 19,67 & & & & & \\
\hline & $\begin{array}{l}\text { Education and } \\
\text { Instructional } \\
\text { Technology }\end{array}$ & & & & & & & \\
\hline
\end{tabular}

No significant difference in the level of reaching art literacy information was found in terms of department variable $(F(6$, $578)=2.01, p>.05$ ). Hence, the levels of reaching art literacy information of art education students are similar.

\section{Conclusion}

According to the results obtained from the findings of this study, it was detected that art literacy level of the students were similar in terms of grade level and gender. When the criteria whether the students like reading art books was observed, it was realized that the art literacy levels of the students enjoying reading books were higher than the students who did not like reading books. These results are consistent with our expectation. Because it is seen how important the habits and attitudes are in human life. When the criteria of enjoying doing research in the library was evaluated, it was realized that the art literacy level of the students enjoying doing research in the library was higher than the students who did not like doing research. In terms of reading frequency; the art literacy level of students who read books on a daily basis was higher than the students who read one book in a month and who read not at all. In terms of the departments; it was observed that the students studying at Turkish Teaching department were more capable in utilizing knowledge of art literacy and defining the need for knowledge of art literacy in comparison with students studying at Psychological Counseling and Guidance and Mathematics Teaching. However, it has been ascertained that there is no significant difference in terms of transforming the knowledge to the performance and using the knowledge between different 
departments. The reason for this result may be the fact that the students of Turkısh Language Teaching program read more books and encounter more written texts than other programs of the faculty. Sever, Kaya and Aslan (2006), state that the aim of Turkish Language Teaching is to train individuals who have acquired reading habit, think and are sensitive and thoughtful. Because of this reason, these candidates may develop the sensitivity to art just as they do for the general aim at their programs.

\section{Suggestions}

It is ascertained that the curriculum (mathematics and science lessons) is not sufficient to the development of young people and children in creativity or in any area since it is the most active time for the thinking ability of children and youth. Hence, it is necessary to include compulsory art lessons with appropriate content and time just as mathematics and science lessons. Furthermore, it is essential to include non-verbal, concrete intuitive thinking approaches aiming to make individuals more active as well as to develop them more. Thus the curriculum can play a prominent role in the training of creative individuals in each field. Workshops for arts education and training should be suitable for the purpose and appropriate equipment should be used. It is necessary to have appropriate tools and equipment to use in the workshops so that the students may develop their handcraft skills and learn different methods and techniques as well as develop their creativity with these practices. Hence, the children and young people shall use appropriate techniques and methods at every stage of their education in order to express themselves in different artistic ways, to develop their sense of responsibility and contribute to their personal development. During the art education, it should be strived to develop the personality of each person. Throughout art education, students should be given enough theoretical knowledge, they should be encouraged to think and speak. Theoretical information should be provided with visual materials (museum and gallery visits, etc.) related to the subject and technique before the application, students should be given brainstorming opportunity before the study by asking questions and providing answers, and the application shall commence after the brainstorming. In addition, the love for art, awareness, and desire for art shall be promoted since the artworks contribute greatly to the spiritual development of children and young people in particular.

\section{References}

Alpan-Bangir, G. (2008). Visual Literacy and Technology of Instruction. Yuzuncu Yll University Faculty of Education Journal, 5(2), 74-102.

Barton, G. (2013). The Arts and Literacy: What Does it Mean to be Arts Literate? International Journal of Education \& the Arts, 14(18), 22.

Buyurgan, S., \& Buyurgan, U. (2012). Art Education and Instruction, (3rd Edition), Ankara: Pegem Publishing.

Csíkos, C., \& Dohány, G. (2016). Connections Between Music Literacy and Music-Related Background Variables: An Empirical Investigation. Visions of Research in Music Education, 28.

Fraenkel, J. E., Wallen, N. E., \& Hyun, H. H. (2011). How to design and evaluate research in education (8th ed). New York, NY: McGraw-Hill.

Gunduz-Kalan, Ö. (2010). Media Literacy and pre-school children: a survey on parent's awareness about media literacy. Istanbul University Communication Faculty Journal, 1(39), 59-73.

Gunes, G., Colaklar, H., Bicen, A. B., \& Turan, A. (2016). Approaches to Media Literacy. Conference on Information Systems, Platforms, Architectures and Technologies, 244-248. Istanbul: Marmara University.

Heinich, R., Molenda, M., \& Russel, J. D. (1989) Instructional media and new technologies of instruction. (Third Edition). Macmillan Publishing Company.

Keefe, E. B., \& Copeland, S. R. (2011). Research \& practice for persons with severe disabilities, University of New Mexico Vol. 36, No. 3-4, 92-99.

Kisoglu, M. (2009). Investigation of the effects of student-centered teaching on the environmental literacy of teacher candidates, Unpublished Ph.D. Dissertation. Ataturk University, Erzurum.

Kurbanoglu, S., \& Akkoyunlu, B. (2002). The effectiveness of information literacy program implemented to teacher candidates and the relationship between information literacy skills and computer self-efficacy perception. Hacettepe University Faculty of Education Journal, 22, 98-105.

National core arts standards: a conceptual framework for arts learning. Access date: 01.03.2018, http://www.nationalartsstandards.org/

Okan-Akın, N., \& Yucetoker, İ. (2016). Application of the art literacy scale in art teaching. VIII. International Educational Research Congress, 1296-1301. Canakkale.

San, İ. (1985). Art and instruction Ankara: Ankara University Faculty of Education Publications. 
Tallim, J. (2010). What is Media Literacy? Media Awareness Network. http//www.media-awareness.ca/english/teachers/media_literacy.cfm. (01.12.2017).

Timur, B., Yılmaz, S., \&Timur, S. (2014). Determination of general trends in studies published between 1992 and 2012 on the environmental literacy. Mehmet Akif Ersoy University Institute of Education Sciences Journal, 3(5), 22-41.

Yucetoker, İ. (2014). Preparation and development of art literacy scale, Art Education Journal, 2(1), 112-126. https://doi.org/10.7816/sed-02-01-06

\section{Art Literacy Scale}

\begin{tabular}{|c|c|c|c|c|c|}
\hline $\begin{array}{l}\text { Dear participant, } \\
\text { This questionnaire is designed to determine the areas you are challenged within your artistic } \\
\text { information as well as your performances. The main purpose of this study is to reveal the } \\
\text { current state of art literacy and to develop suggestions that will fulfill your needs after } \\
\text { comprehending your perspectives. Please read the following statements and select the } \\
\text { relevant option. }\end{array}$ & 利 & 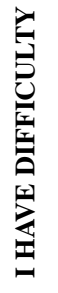 & 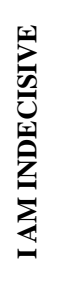 & 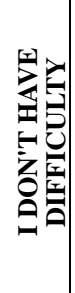 & 罗 \\
\hline \multicolumn{6}{|l|}{ 1: When I have to determine the location of my artistic research } \\
\hline \multicolumn{6}{|l|}{ 2: In developing and narrowing the scope of my artistic research } \\
\hline \multicolumn{6}{|l|}{ 3: In knowing how and where to find information about music/painting } \\
\hline \multicolumn{6}{|l|}{ 4: In knowing what resources are appropriate for my research } \\
\hline \multicolumn{6}{|l|}{ 5: In using international art resources (magazines, books, encyclopedias) } \\
\hline \multicolumn{6}{|l|}{ 6: In using Artistic Web Resources } \\
\hline \multicolumn{6}{|l|}{ 7: In finding information about location from web search engines } \\
\hline \multicolumn{6}{|l|}{ 8: In limiting the research conducted on the computer (language, history, genre) } \\
\hline \multicolumn{6}{|l|}{ 9: In getting information from the people I see or the people I talk to } \\
\hline \multicolumn{6}{|l|}{ 10: In using art catalogs in libraries } \\
\hline \multicolumn{6}{|l|}{ 11: In using libraries in other places besides the libraries that I know } \\
\hline \multicolumn{6}{|l|}{$\begin{array}{l}\text { 12: In understanding the relevancy of the information I obtained on the research for my } \\
\text { subject }\end{array}$} \\
\hline \multicolumn{6}{|l|}{ 13: In identifying similar and different points between many artistic publications } \\
\hline \multicolumn{6}{|l|}{ 14: In correlating the information I obtained with the works I have drawn/listened to } \\
\hline \multicolumn{6}{|l|}{ 15: In commenting the information I read in art books } \\
\hline \multicolumn{6}{|l|}{ 16: In correlating the information I have read previously and the information I have just read } \\
\hline \multicolumn{6}{|l|}{ 17: In reflecting on my work whatever I learned about the work I am going to draw/listen to } \\
\hline \multicolumn{6}{|l|}{ 18: In using many resources in the art research } \\
\hline \multicolumn{6}{|l|}{ 19: In organizing the sections of the assignment while completing theoretical assignments } \\
\hline \multicolumn{6}{|l|}{ 20: In preparing the list of the sources I used in my theoretical assignments } \\
\hline \multicolumn{6}{|l|}{ 21: In preparing the results of my theoretical works in writing } \\
\hline \multicolumn{6}{|l|}{ 22: In presenting verbally the results of my theoretical studies of music/painting } \\
\hline \multicolumn{6}{|l|}{ 23: In using technology tools when completing my Musical Work/Painting } \\
\hline \multicolumn{6}{|l|}{ 24: In defining the strengths and weaknesses of my performance work } \\
\hline \multicolumn{6}{|l|}{ 25: In criticizing the strengths and weaknesses of my theoretical studies } \\
\hline 26: In reconfiguring the artistic information by sharing with others & & & & & \\
\hline
\end{tabular}

\section{Copyrights}

Copyright for this article is retained by the author(s), with first publication rights granted to the journal.

This is an open-access article distributed under the terms and conditions of the Creative Commons Attribution license which permits unrestricted use, distribution, and reproduction in any medium, provided the original work is properly cited. 